\title{
RISK FACTORS FOR FAILURE TO REACH TOTAL ENERGY VALUE IN AN INTENSIVE CARE UNIT
}

\section{Louise Carnevali Furtado de Medeiros}

Nutricionista. Especialista em Terapia Intensiva pelo Programa de Residência Multiprofissional com Ênfase em Terapia Intensiva pela Universidade Federal do Acre (UFAC), Brasil.

\section{Cláudia Sena de Pádua}

Nutricionista. Mestranda do Programa de Ciências da Saúde da Universidade Federal do Acre (UFAC), Brasil.

\section{Irla Maiara Silva Medeiros}

Especialista em Terapia Intensiva através do Programa de residência Multiprofissional com Ênfase em Terapia Intensiva, pela Universidade Federal do Acre (UFAC), Brasil.

\section{Monica Silvina Maia Nascimento}

Enfermeira. Especialista em UTI pela Pontifícia Universidade Católica de Goiás (PUC/GO) e Universidade Nove de Julho (UNINOVE/SP), Brasil.

\section{Thatiana Lameira Maciel Amaral}

Doutorado em Saúde Pública e Meio Ambiente (ENSP/ FIOCRUZ). Docente das disciplinas de Enfermagem Fundamental e Enfermagem em Clínica Médico-Cirúrgica, no Centro de Ciências da Saúde e Desporto da Universidade Federal do Acre (UFAC), Brasil.

\section{Patricia Rezende do Prado}

Doutorado pela Escola Paulista de Enfermagem da Universidade Federal de São Paulo (EPE/UNIFESP). Docente Adjunto I da Universidade Federal do Acre (UFAC), Brasil.

\begin{abstract}
The objective was identify the risk factors associated with the failure to total energy value. A prospective cohort study was conducted in an intensive care unit with 87 patients receiving exclusive enteral nutrition therapy. The Kaplan-Meier and Cox regression analysis were used to evaluate the results. Regarding the patients, 35.6\% were aged between 31 and 50 years, and 58.6\% were males. At the end of the third day, $70.8 \%$ reached the total recommended energy value. Postoperative patients (HR: 7.09; 95\% CI: 2.02-24.81), hemodynamically unstable patients (HR: $5.97 ; 95 \%$ CI: 1.11-31.99) and those who were fasting for the performance of tests (HR: $4.95 ; 95 \% \mathrm{CI}$ : 1.01-24.61) presented a greater risk of not reaching the recommended value. The number of patients who achieved the total energy value was adequate, but can be optimized by the evaluation of these identified factors.
\end{abstract}

KEY WORDS: Enteral nutrition; Risk factors; Critical care; Nutrition therapy; Patient care.

\section{FATORES DE RISCO PARA FALHA NO ALCANCE DO VALOR ENERGÉTICO TOTAL EM UMA UNIDADE DE TERAPIA INTENSIVA}

RESUMO: O objetivo deste trabalho foi identificar os fatores de risco associados à falha em alcançar o valor energético total em pacientes internados em uma UTI. Trata-se de um estudo de coorte prospectivo realizado com 87 pacientes em uso de terapia nutricional enteral. A análise de Kaplan-Meier e regressão de Cox foram utilizadas para avaliar os resultados. Em relação aos pacientes, $35,6 \%$ tinha idade entre 31 e 50 anos e 58,6\% eram do sexo masculino. No final do terceiro dia, 70,8\% atingiram o valor energético total. Pacientes no pós-operatório (HR: 7,09; IC95\%: 2,02-24,81), os hemodinamicamente instáveis (HR: 5,97; IC95\%: 1,11-31,99) e aqueles que estavam em jejum para a realização de exames (HR: 4,95; IC95\%: 1,01-24,61) apresentaram maior risco de não atingir a recomendação do valor energético total. $\mathrm{O}$ número de pacientes que atingiram o valor energético total foi adequado, mas pode ser otimizado pela avaliação desses fatores identificados.

PALAVRAS-CHAVE: Nutrição enteral; Fatores de risco; Cuidado intensivo; Terapia nutricional; Assistência ao paciente. 


\section{INTRODUCTION}

Hospitalization is an independent risk factor for malnutrition. In Brazil, a cross-sectional study performed in a general hospital located in São Paulo, in a sample of 300 adult individuals, the malnutrition occurred in $60.7 \%$ of them and the variables associated with malnutrition were recent and involuntary weight loss, apparent bony structure, decreased appetite, diarrhea, inadequate energy intake and male sex ${ }^{1}$.

Among intensive care unit (ICU) patients, factors such as metabolism, catabolism, prolonged immobilization and poor nutritional support may be associated with a negative energy balance, which occurs when energy expenditure exceeds energy intake, thereby increasing the risk of nutritional deficiencies ${ }^{2}$. So, in a case series study conducted with a sample of 45 patients of both sexes, aged between 18 and 99 years admitted in an intensive care unit in Pernanbuco, Brazil, in 2011, the majority of the sample had gastrointestinal complications (55.6\%) and 68.9\% died. Among the gastrointestinal complications, diarrhea was the most common complication ${ }^{3}$.

Considering that early and adequate nutritional therapy (NT) in critically ill patients is an important factor for promoting health, decreasing physiological stress and maintaining immunity, assessing the suitability of this treatment is essential. The goals of NT include providing adequate nutritional support, preventing nutritional deficiencies, attenuating the loss of lean body mass, preventing complications and improving clinical outcomes. Enteral feeding is an important therapeutic modality because the patients undergoing this type of therapy may be partially or totally unable to ingest and/ or digest food orally. So, in an observational study with adult patients hospitalized in intensive care unit having an exclusive enteral nutrition therapy for more than 72 hours, these patients received less enteral diet than prescribed $^{4}$.

A study has demonstrated that critically ill patients receive lower volumes of enteral nutrition (EN) and do not reach the recommended energy intake, what is a problem for their rehabilitation 5 . In this sense, some factors that prevent adequate nutritional support are associated with dietary intolerance, including vomiting, diarrhea, gastric residue and abdominal distension, with nursing routines such as the manipulation of patients and drug administration and with medical routines such as procedures and tests.

An attention to and knowledge of the factors that hinder the effective administration of EN therapy (ENT) allow adopting measures designed to help patients achieve the total energy value (TEV). Thus, the objective of this study was to identify the risk factors associated with the failure to achieve the TEV among patients in an ICU in the Western Brazilian Amazon.

\section{METHOD}

This prospective cohort study was performed at an ICU located in the Western Brazilian Amazon.

Data were collected daily through interviews, from medical records, from daily notes made by the nursing team and from the nutritional balance record of patients undergoing exclusive ENT between January and September 2016. The patients were monitored to calculate the TEV and its adequacy, starting at the first day of hospitalization (T0).

All the patients were evaluated by a nutritionist based on Guidelines for the Provision and Assessment of Nutrition Support Therapy in the Adult Critically Ill Patient: Society of Critical Care Medicine (SCCM) and American Society for Parenteral and Enteral Nutrition (A.S.P.E.N.), in which an estimate of $25-35 \mathrm{kcal} / \mathrm{kg} /$ day is used to calculate a patient's energy requirements ${ }^{6}$.

The body weight used to calculate the TEV was obtained from the patient's medical record. The type of enteral formula and the diet infusion rate utilized to achieve the nutritional goal were determined based on the TEV and the clinical condition of the patient. A value greater than $70 \%$ of the TEV was considered satisfactory within 72 hours of enteral nutrition ${ }^{6}$.

The patients received ENT through orogastric, nasogastric or nasoenteric tubes. All the diets were administered by cyclic infusion using an infusion pump on a schedule of $18 \mathrm{~h} /$ day. The initial infusion rate was $30 \mathrm{~mL} / \mathrm{h}$, and this rate progressed according to the tolerance of the patient. 
In this cohort, time zero (T0) was the first day of the enteral diet, and the follow-up time $(\Delta \mathrm{T})$ was considered satisfactory within 72 hours of enteral nutrition and the value greater than $70 \%$ of the TEV was considered satisfactory, as recommended by the ASPEN. ${ }^{6}$ This time was considered because after 72 hours most of the cohort patients initiate oral diet or out of hospital discharge, making it difficult to follow.

The Kaplan-Meier conditional probability approach was used to estimate the conditional probability of failure to achieve the TEV of follow-up; a log-rank test at $95 \%$ significance was used to assess the differences between the curves.

A Cox regression analysis with crude and adjusted hazard ratios (HRs) and their respective 95\% confidence intervals (95\% CIs) were used to assess the risk factors associated with the failure to achieve the TEV.

The final model was built to evaluate the risk factors/failure to achieve the TEV among the ICU patients. Independent variables that were statistically significant in the univariate analysis $(\mathrm{p}<0.05)$ were included in the multivariate Cox regression model.

The data were organized in Excel 2010 (Microsoft, USA) and analyzed using SPSS version 20.0 (SPSS Corp., Chicago, USA).

This project was approved by the Research Ethics Committee of the State Hospital Foundation of Acre (Fundação Hospital Estadual do Acre), protocol no. 1.336.173 and followed resolution 466/2012 of the Brazilian National Research Ethics Commission
(Comissão Nacional de Ética em Pesquisa - CONEP). All patients or caregivers signed and received a copy of the informed consent form.

\section{RESULTS}

This study was conducted with 87 patients who met the inclusion criteria, with $35.6 \%$ of the patients aged between $31-50$ years and 35.6\% over 50 years of age. The majority of the patients were male (58.6\%) and married (65.8\%) (Table 1).

The main diagnoses at admission were traumatic brain injury $(32.8 \%)$, respiratory failure (20.3\%), polytrauma (15.6\%) and stroke (14.1\%). A total of $66.7 \%$ of the patients were sedated, and $65.5 \%$ were receiving mechanical ventilation and $70.8 \%$ of the patients achieved the TEV (Table 1).

Table 1. Epidemiological characteristics of the ICU patients and corresponding probability of failure to achieve the TEV. Rio Branco, AC, Brazil, 2016

(Continue)

\begin{tabular}{|c|c|c|c|c|c|}
\hline & & $\mathbf{N}^{*}$ & $\%$ & $\%$ failure & $p$-value \\
\hline \multirow{3}{*}{ Age } & $<30$ years old & 25 & 28.8 & 42.1 & \multirow{3}{*}{0.03} \\
\hline & 3-50 years old & 31 & 35.6 & 8.3 & \\
\hline & $>50$ years old & 31 & 35.6 & 34.8 & \\
\hline \multirow{2}{*}{ Gender } & Male & 51 & 58.6 & 27.5 & \multirow{2}{*}{0.95} \\
\hline & Female & 36 & 41.4 & 29.9 & \\
\hline \multirow{2}{*}{ Marital status* } & Married & 25 & 65.8 & 40.0 & \multirow{2}{*}{0.46} \\
\hline & Single & 13 & 34.2 & 33.3 & \\
\hline
\end{tabular}


(Conclusion)

\begin{tabular}{|c|c|c|c|c|c|}
\hline \multicolumn{2}{|c|}{ Variable } & $\mathrm{N}^{*}$ & $\%$ & $\%$ failure & p-value \\
\hline \multirow{6}{*}{ Medical diagnosis* } & TBI & 21 & 32.8 & 26.7 & \multirow{6}{*}{0.21} \\
\hline & ARF & 13 & 20.3 & 9.1 & \\
\hline & Polytrauma & 10 & 15.6 & 40.0 & \\
\hline & Stroke & 09 & 14.1 & 22.2 & \\
\hline & $\mathrm{FAI} / \mathrm{CWI}$ & 06 & 9.4 & 25.0 & \\
\hline & Acute abdomen & 05 & 7.8 & 75.0 & \\
\hline \multirow{2}{*}{ General condition } & Sedated & 58 & 66.7 & 21.1 & \multirow{2}{*}{0.47} \\
\hline & Conscious & 29 & 33.3 & 29.8 & \\
\hline \multirow{2}{*}{ Mechanical ventilation } & Yes & 57 & 65.5 & 31.1 & \multirow{2}{*}{0.30} \\
\hline & No & 30 & 34.5 & 19.0 & \\
\hline \multirow{3}{*}{ Diet administration** } & NET & 43 & 49.4 & 11.4 & \multirow{3}{*}{0.46} \\
\hline & OGT & 13 & 15.0 & 23.1 & \\
\hline & NGT & 31 & 35.6 & 36.0 & \\
\hline
\end{tabular}

* Cases can vary because of missing data. NET: nasoenteric tube; OGT: orogastric tube; NGT: nasogastric tube; TBI: traumatic brain injury; ARF: acute respiratory failure; FAI/CWI: firearm injury/cold weapon injury; OA: oral administration

On the first day, $81.5 \%$ of the patients received were that the patient was in the immediate postoperative ENT and achieved 35\% or more of their TEV. The primary period (59\%) or had hemodynamic instability (29\%) reasons some patients did not receive ENT on the first day (Table 2).

Table 2. Characteristics of the ICU patients and corresponding probability of failure to achieve the TEV. Rio Branco, AC, Brazil, 2016

\begin{tabular}{|c|c|c|c|c|c|}
\hline & & & & & (Continue \\
\hline & Variable & $\mathrm{N}^{*}$ & $\%$ & $\%$ failure & p-value \\
\hline & $>=35 \%$ & 70 & 81.5 & 23.3 & \\
\hline ICV UII Lay 1 & Did not receive diet & 17 & 19.5 & 54.5 & $0.0 \mathrm{~J}$ \\
\hline & Postoperative & 10 & 59.0 & 71.4 & \\
\hline Reason for not receiving diet & Hemodynamic instability & 05 & 29.0 & 66.7 & 0029 \\
\hline on day 1 & Record error & 01 & 6.0 & 16.7 & \\
\hline & Reason not reported & 01 & 6.0 & - & \\
\hline & Up to $35 \%$ & 14 & 16.1 & 81.8 & \\
\hline Tey on day 2 & 35 to $69 \%$ & 31 & 35.6 & 18.5 & $<0001$ \\
\hline & $>70 \%$ & 30 & 34.5 & 4.0 & \\
\hline & Did not receive diet & 12 & 13.8 & 100.0 & \\
\hline & Death & 03 & 25.0 & - & \\
\hline & Procedure/test & 03 & 25.0 & 36.4 & \\
\hline $\begin{array}{l}\text { Reason for not receiving diet } \\
\text { on dav } 2\end{array}$ & Catheter removal & 02 & 16.7 & - & 0.20 \\
\hline & Hemodynamic instability & 01 & 8.3 & 50.0 & \\
\hline & Reason not reported & 03 & 25.0 & - & \\
\hline
\end{tabular}




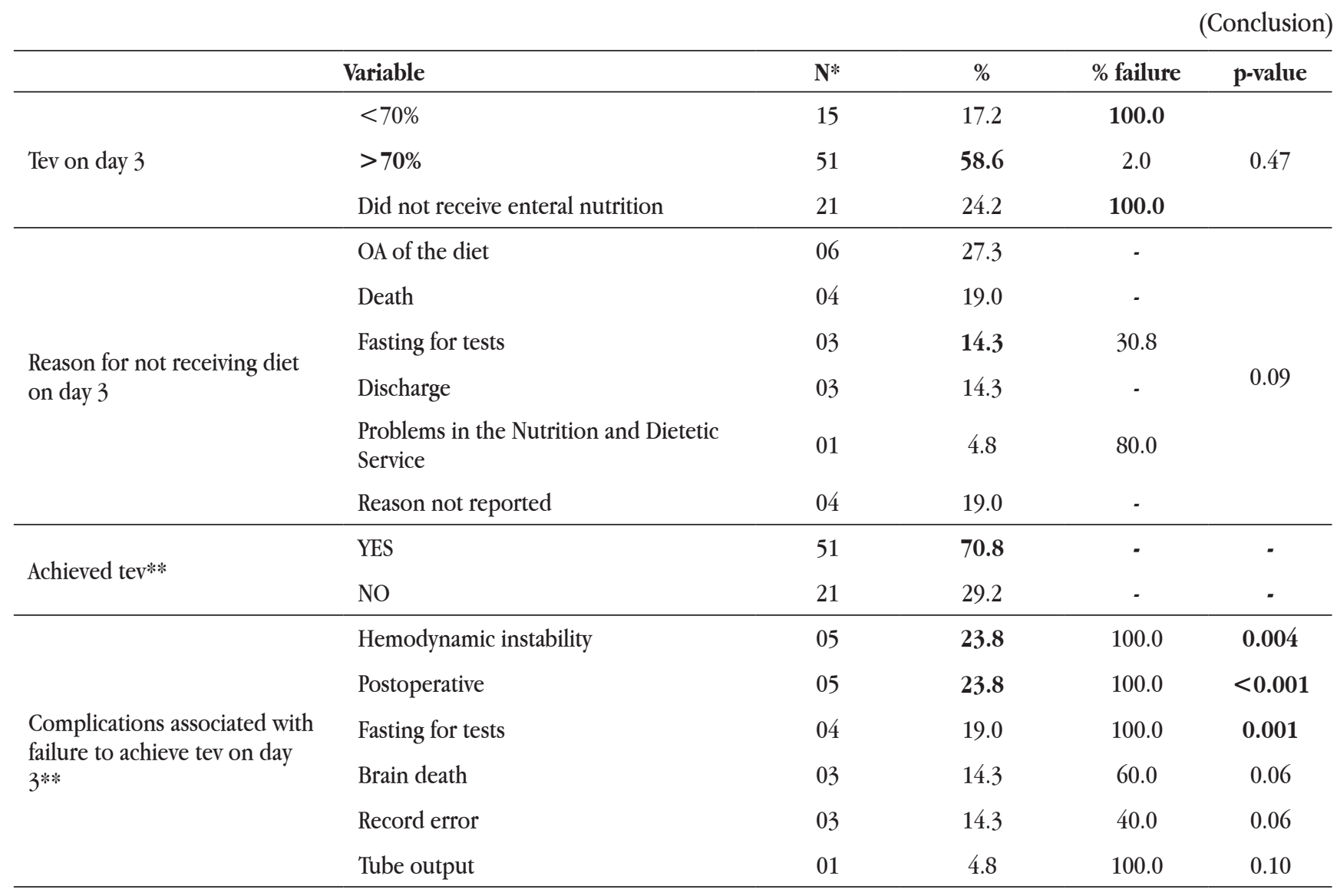

*Cases can vary because of missing data. **Patients who did not receive the diet due to discharge or death or those who started an oral diet were excluded.

On the second day of follow-up, $86.2 \%$ of the patients achieved greater than $35 \%$ of the TEV. The main reasons some patients did not receive ENT were death and fasting for procedures and tests (25\% each) (Table 2). At the end of the third day, $70.8 \%$ of the patients achieved the TEV. The main causes associated with the failure to achieve the TEV were postoperative period and had hemodynamic instability, 23.8\% each, $19.0 \%$ fasting for procedures and tests and brain death (14.3\%) (Table 2).

Table 3. Univariate and multivariate analyses of risk factors for failure to achieve the TEV. Rio Branco, AC, Brazil, 2016

(Continue)

\begin{tabular}{cccc}
\hline & \multicolumn{1}{c}{ Variable } & $\mathbf{N}^{*}$ & $\%$ \\
\hline \multirow{3}{*}{ Age } & $<30$ years old & $1.21(0.45-3.22)$ & $0.87(0.31-2.42)$ \\
& $3-50$ years old & $0.24(0.05-1.12)$ & $0.38(0.07-2.01)$ \\
& $>50$ years old & 1 & 1 \\
\hline
\end{tabular}

In the final analysis, postoperative patients (HR: 7.09; 95\% CI: 2.02-24.81), hemodynamically unstable patients (HR: 5.97 ; $95 \% \mathrm{CI}$ : 1.11-31.99) and patients who fasted for the performance of tests (HR: 4.95; $95 \% \mathrm{CI}$ : 1.01-24.61) had a higher risk of failing to achieve greater than $70 \%$ of the TEV at the end of the third day of follow up (Table 3). 
(Conclusion)

\begin{tabular}{llcc}
\hline \multicolumn{1}{c}{ Variable } & \multicolumn{1}{c}{$\mathbf{N}^{*}$} & $\%$ \\
\hline & $\begin{array}{l}\text { Hemodynamic } \\
\text { instability }\end{array}$ & $4.20(1.21-14.50)$ & $5.97(1.11-31.99)$ \\
$\begin{array}{l}\text { Complications } \\
\text { associated with failure } \\
\text { to achieve TEV on day } \\
3^{* *}\end{array}$ & Postoperative & $4.70(1.67-13.16)$ & $7.09(2.02-24.81)$ \\
& Fasting for tests & $4.42(1.45-13.45)$ & $4.95(1.01-24.61)$ \\
& $\begin{array}{l}\text { Hemodynamic } \\
\text { instability }\end{array}$ & $4.20(1.21-14.50)$ & $5.97(1.11-31.99)$ \\
\hline
\end{tabular}

**adjusted according to the variables above and the TEV on day 3

\section{DISCUSSION}

Studies have shown that the percent caloric target administered via ENT in ICU patients is variable and can reach $50 \%$ to $100 \%$ of the desired calorie goal $^{7-8}$. Accordingly, the TEV percentage of greater than $70 \%$ that was observed in the ICU analyzed in this study meets the recommended calorie goal because $70.8 \%$ of the patients achieved the TEV at the end of the third day of follow up.

Some patients received inadequate ENT administration due to factors that did not allow the infusion of the diet as planned, whose causes were different from those found in another studies. Some studies have pointed out that gastrointestinal disturbances, especially diarrhea, as the main factor in not achieving TEV, a fact not identified in this study ${ }^{3,4}$.

Anotherimportantfactoristheearlyintroduction of the diet at 24 and $48 \mathrm{~h}$ after hospital admission benefits the patient, preventing a poor nutritional status and, consequently, malnutrition but, nutritional therapy is not always started early and the reason is that nutrition is not necessarily the first therapeutic priority of the treating physicians. Instead, nutritional support is generally started later in the ICU course, is slow to reach a designated target and practitioners are reluctant to prescribe parenteral nutrition where enteral nutrition does not meet the metabolic needs, which should be reviewed $^{7-9}$.

The administration of ENT is hampered by factors directly associated with intensive therapy, such as hemodynamic instability, fasting for the performance of procedures and tests, an interruption for drug administration by gavage and bathing, among another factors $^{7 \cdot 10}$.
The present study revealed that ENT was initiated within 24 to $48 \mathrm{~h}$ after ICU admission. This result is consistent with current recommendations of the early onset of $\mathrm{NT}^{11-12}$. However, the second leading cause of diet interruption was being within the immediate postoperative period, which occurred in $23.8 \%$ of the patients.

A meta-analysis demonstrated that starting ENT within $24 \mathrm{~h}$ had a significant effect on reducing mortality ${ }^{6,13}$ The recommendations for the early onset of ENT are supported by the premise that a negative energy balance is associated with worse outcomes, and the earlier that the administration is initiated and the nutritional goal is achieved, the lower the probability of extremes in the energy balance ${ }^{4-14}$.

As expected, because these were critically ill patients, hemodynamic instability (23.8\%) was an important reason for delaying the start of ENT, as indicated by the guidelines ${ }^{10,14}$. In a hospital in southern Brazil, 32.3\% of patients presented hemodynamically unstable and not started the ENT ${ }^{10}$.

Hemodynamic instability is defined as abnormal or unstable blood pressure that provides insufficient global or peripheral perfusion, which hampers the proper functioning of organs. From the nutritional support point of view, a hemodynamically unstable patient is one who has surpassed the first 6-24h of shock intervention, is receiving vasoactive drugs to ensure an adequate tissue oxygen supply and still maintains signs of tissue hypoperfusion ${ }^{15}$.

The safety at the beginning of nutritional support for hemodynamically unstable patients is still under debate. Hypoperfusion may originate in the 
gastrointestinal tissues, making it the primary target of therapeutic support actions ${ }^{16}$. Minimally preserved motility, absorptive capacity and barrier function are prerequisites for using the gastrointestinal tract. The greatest advantages of the early onset of EN among hemodynamically unstable patients are favoring the distribution of splanchnic blood flow due to the presence of food, the functional preservation of the mucosal barrier, the modulation of the neuroendocrine response, reducing metabolic stress, supplying energy to cells and the attenuation of bacterial translocation ${ }^{16}$.

The neuroendocrine and exocrine responses of the gastrointestinal tract to food are different in hemodynamically unstable patients ${ }^{17}$. A multicenter prospective observational study involving over 200 patients admitted to the ICU analyzed the volume of gastric residue and the correlation of this residue with increased morbidity and mortality and supported the recommendation as a way to promote greater safety in the adjustment to $\mathrm{EN}^{18-19}$. In contrast, an experimental study conducted with 24 rats with intestinal hypoxia indicated a potential deleterious effect of nutrient stimulation at an inopportune time, exacerbating the oxygen deficit and increasing cellular damage ${ }^{20}$.

A prospective descriptive study performed in the ICU of a teaching hospital with 70 randomized patients revealed that hemodynamically unstable, nonseptic surgical patients tolerated the use of NT. The study described the tolerance of EN in hemodynamically unstable patients who had required intra-aortic balloonpump support and vasoactive drugs during cardiac surgery, suggesting that this route can be used for most patients. However, reduced ENT administration while monitoring abdominal and oxydynamic variables is important ${ }^{21}$.

Although evidence for the practice of early EN is accumulating, the nutrition of hemodynamically unstable patients presents potential risks. Currently, EN is not recommended for hemodynamically unstable septic patients until there is a better understanding of when to begin ENT, what nutrients will be useful to change the local and systemic response and how to monitor the local effect of the diet ${ }^{15}$.

Another cause that contributed to the failure to achieve the TEV in this ICU was fasting to undergo procedures and tests (19\%). In a study carried out in a university hospital in São Luis, hospitalized in ICU and receiving continuous enteral feeding, discontinuation of diet administration for tests and procedures was also the main reason, accounting for $20.2 \%$ of the total interruption in the study ${ }^{22}$. The same cause was found in a hospital in southern Brazil, where procedures accounted for $44.1 \%$ of nutrition interruptions ${ }^{10}$.

An adequate TEV percentage was observed in $70.8 \%$ of the patients from this ICU in the Brazilian Amazon. It is important to note that the mean adequacy between the prescribed and administered nutrition was $50 \%$, and only one-third of the patients received more than $65 \%$ of the prescribed $\mathrm{TEV}^{23}$. These data indicate that the TEV observed in the unit is satisfactory. In a hospital in southern Brazil, only $50.0 \%$ of patients achieved caloric and protein target on the third day of hospitalization ${ }^{10}$.

However, another study found that $92 \%$ of patients received more than $70 \%$ of the prescribed calories $^{24}$. In addition to the early onset of EN, the guidelines recommend that this therapy should have the proper amount of nutrients, meaning that patients should receive $65 \%$ of the needs in the first 3 days of hospitalization and should reach the full target within the first 7 days ${ }^{10,24}$.

Another observation in the current guidelines is that enteral nutritional support should not be initiated in the presence of systemic low blood flow and/or high doses of vasopressors (i.e., noradrenaline $>50-100 \mu \mathrm{g} /$ min with signs of poor tissue perfusion) due to the risk of developing intestinal ischemic syndrome ${ }^{6,25}$.

Pain and abdominal distension are the most prevalent symptoms of systemic low flow, but metabolic acidosis of unknown origin and gastrointestinal bleeding may be part of the clinical condition. The risk of metabolic complications with the parenteral administration of nutrients under low blood flow conditions is high and requires frequent monitoring and slow progression. Careful hydration to correct reduced blood flow without the intention of feeding the patient is the most appropriate course of action ${ }^{6,25}$.

However, given the frequency of interruptions in the supply of EN, the present study indicates the need to promote efforts on the part of the multidisciplinary team to ensure that the prescribed diet is administered. 
An important aspect is related to the protein supply in critically ill patients. Adequate protein supply appears to be related reduction of morbidity and mortality in critically ill patients. Currently appear strong evidence in the literature that the use of higher concentrations protein (>1.2 g ptn.kg-1.d-1) is associated with reduce morbidity and mortality in this population. However, most studies are needed to determine the mechanisms of action and the optimal dose of higher concentrations protein in the nutritional formula. In any case, a new principle seems to establish itself: in addition to the caloric needs, the ideal protein target should be pursued; hit it full so could mean a clinical impact and prognosis as or more important than filling isolated calorie goal ${ }^{26}$.

Compared with the recommendations, the values observed in this study reflect consistent practices that help define the measures necessary to achieve the TEV, as well as the effort of the multidisciplinary team to minimize the fasting time for performing procedures and tests.

The sample size is a limitation that prevents generalized conclusions. However, this is an important study for this ICU because the results identified factors that can be adjusted to achieve greater than $70 \%$ of the TEV among critically ill ICU patients.

Despite certain limitations observed in this study, it was possible to identify the factors that interfered with the administration of the diet due to the existence of nutrition and nursing protocols that provided the necessary patient information. However, protocols for pre- and postoperative patients, as well as hemodynamically unstable patients, must be better defined by the multidisciplinary team to prevent these factors from contributing to the failure to achieve the TEV.

\section{CONCLUSION}

A satisfactory total energy value was reached at the end of the third day of follow-up at this ICU in the Brazilian Western Amazon. The main factors for the failure to obtain VET were postoperative period, tests and hemodynamic instability.
The evaluation of the patient in the postoperative period, with the early start of an EN diet, as well as the organization of procedures and tests to prevent the patient from fasting for long periods of time, can help patients reach a VTE. Another important point is to carefully nourish the patient with hemodynamic instability, aiming at reestablishing his health but paying attention to the specificities of hypoperfusion of the gastrointestinal organs.

In this sense, the team's care to limit nutrition discontinuity is essential. Other studies may also be carried out to verify the protein supply in these patients.

\section{ACKNOWLEDGMENTS}

We thanks Education and Culture Ministry, Ministério da Educação e Cultura (MEC) for financial support in Multidisciplinary Residency Program with an emphasis on Intensive Care at Universidade Federal do Acre.

\section{REFERENCES}

1. Aquino RC, Philippi ST. Identification of malnutrition risk factors in hospitalized patients. Rev. Assoc. Med. Bras. 2011; 57(6): 6235-41.

2. Thibault R, Pichard C. Nutrition and clinical outcome in intensive care patients. Curr Opin Clin Nutr Metab Care. 2010; 13(2):177-83. Review.

3. Lins NF, Dias CA, Oliveira MGOA, Nascimento CX, Barbosa JM. Adequação da terapia nutricional enteral em pacientes críticos de um centro de referência em Pernambuco. Rev Bras Nutr Clin. 2015; 30 (1):76-81.

4. Stefanello MD, Poll FA. Nutritional status and enteral diet prescribed and received by patients of an intensive care unit. ABCS Health Sci. 2014; 39(2):716.

5. Ribeiro PC, Souza IAO. Complicações Relacionadas à Nutrição Enteral. In: Ribeiro PC. Nutrição. Série medicina de Urgência e Terapia Intensiva do Hospital 
Sírio Libanês. São Paulo: Atheneu, 2015. p. 119-35.

6. McClave AS, Taylor BE, Martindale RG, Warren MM, Johnson DR, Braunschweig C, McCarthy MS, Davanos E, Rice TW, Cresci GA, Gervasio JM, Sacks GS, Roberts PR, Compher C; Society of Critical Care Medicine; American Society for Parenteral and Enteral Nutritional. Guidelines for the Provision and Assessment of Nutrition Support Therapy in the Adult Critically Ill Patient: Society of Critical Care Medicine (SCCM) and American Society for Parenteral and Enteral Nutrition (A.S.P.E.N.). JPEN J Parenter Enteral Nutr. 2016; 40(2):159-211.

7. Costa CAD, Tonial CT, Garcia PCR. Relação do estado nutricional com desfechos em pacientes pediátricos críticos - Revisão sistemática. J. Pediatr. 2016; 92(3):223-9.

8. Pereira DJ, Wady MTB, Velarde LGC. Adequação energética e proteica de pacientes em terapia nutricional enteral internados em uma Unidade de Terapia Intensiva. BRASPEN J. 2016;31(3):219-25.

9. Sandoval LCN, Chaud DMA. Adequação da terapia nutricional enteral em pacientes críticos: uma revisão. Série Ciências da saúde. 2016;17(3): 459-72.

10. Pasinato VF, Berbigier MC, Rubin BA, Castro K, Moraes RB, Perry ID. Enteral nutritional therapy in septic patients in the intensive care unit: compliance with nutritional guidelines for critically ill patients. Rev Bras Ter Intensiva. 2013;25(1):17-24.

11. McClave SA, Taylor B, Martindale RG, Warren MM, Johnson DR, McCarthy M, et. al. Guidelines for the Provision and Assessment of Nutrition Support Therapy in the Adult Critically Ill Patient: Society of Critical Care Medicine (SCCM) and American Society for Parenteral and Enteral Nutrition (ASPEN). JPEN J Parenter Enteral Nutr. 2016;40(2):159-211.

12. Rousseau AF, Losser MR, Ichai C, Berger MM. ESPEN endorsed recommendations: Nutritional therapy in major burns. Clin Nutr. 2013;32:497-50.

13. Associação Médica Brasileira e Conselho Federal de Medicina. Projeto Diretrizes, volume IX, São Paulo; 2011.
14. Singer P, Pichard C, Heidegger CP, Wernerman J. Considering energy deficit in intensive care unit. Curr Opin Clin Nutr Metab Care. 2010;13(2):170-6.

15. Associação de Medicina Intensiva Brasileira; Sociedade de Infectologia; Sociedade Brasileira de Nutrição Parenteral e Enteral; Instituto Latino Americano de Sepse. Diretrizes Clínicas na Saúde Suplementar. Sepse: Nutrição. 2011. [Citado em: 2017 Out 29]. Disponível em: http://www.diretrizes. amb.org.br/ans/sepse-nutricao.pdf.

16. Singer P, Cohen J. How could we make nutrition in the intensive care unit simple? Rev Bras Ter Intensiva. 2016;28(4):369-72.

17. Guerin L, Monnet X, Teboul J. Monitoring volume and fluid responsiveness: from static to dynamic indicators. Best Practice \& Research Clinical Anaesthesiology, 2013;Jun;27(2):177-85.

18. Telles JLH, Boton CRM, Mariano MLL, De Paula MAB. Nutrição enteral: complicações gastrointestinais em pacientes de uma unidade de terapia intensive. Rev Recien. 2015;5(13):5-11.

19. Ribeiro PC, Souza IAO. Complicações Relacionadas à Nutrição Enteral. In: Ribeiro PC. Nutrição. Série medicina de Urgência e Terapia Intensiva do Hospital Sírio Libanês. São Paulo: Atheneu; 2015.

20. Kles KA, Wallig MA, Tappenden KA. Luminal nutrients exacerbate intestinal hypoxia in the hypoperfused jejunum. JPEN J Parenter Enteral Nutr. 2001;25(5):246-53.

21. Berger MM, Revelly JP, Cayeux MC, Chiolero RL. Enteral nutrition in critically ill patients with severe hemodynamic failure after cardiopulmonary bypass. Clin Nutr. 2005;24(1):124-32.

22. Rocha AJSC, Oliveira ATV, Cabral NAL, Gomes RS, Guimarães TA, Rodrigues WB. et al. Causes of interruption of enteral nutrition in intensive therapy units. Rev Pesq Saúde. 2017;18(1):49-53.

23. Arabi YM, Haddad SH, Tamim HM, Rishu AH, Sakkijha 
$\mathrm{MH}$, Kahoul SH, et al. Near-target caloric intake in critically ill medical-surgical patients is associated with adverse outcomes. JPEN J Parenter Enteral Nutr. 2010;34(3):280-8.

24. Oliveira NS, Caruso L, Bergamaschi DP, Cartolano Fde C, Soriano FG. Impact of the adequacy of energy intake on intensive care unit mortality in patients receiving enteral nutrition. Rev Bras Ter Intensiva. 2011;23(2):183-9.

25. Mendes PV, Taniguchi LT. Avaliação nutricional do doente crítico: quando iniciar a terapia nutricional. In: Toledo D, Castro M. Terapia Nutricional em UTI. Rio de Janeiro: Rubio; 2015.

26. Cunha HF, Rocha EE, Hissa M. [Protein requirements, morbidity and mortality in critically ill patients: fundamentals and applications]. Rev Bras Ter Intensiva. 2013;25(1):49-55.

Recebido em: 23/01/2018

Aceito em: 25/05/2018 